\title{
INFLUENCE OF THE TOOL ROTATIONAL SPEED ON THE MICROSTRUCTURE AND JOINT STRENGTH OF FRICTION-STIR SPOT-WELDED PURE COPPER
}

\author{
VPLIV HITROSTI VRTENJA ORODJA NA MIKROSTRUKTURO IN \\ TRDNOST TORNO VRTILNO TOČKASTO ZVARJENEGA SPOJA \\ ČISTEGA BAKRA
}

\author{
Isaac Dinaharan, Esther T. Akinlabi \\ University of Johannesburg, Department of Mechanical Engineering Science, Auckland Park, Kingsway Campus, \\ Johannesburg 2006, South Africa \\ dinaweld2009@gmail.com \\ Prejem rokopisa - received: 2015-09-21; sprejem za objavo - accepted for publication: 2015-10-05
}

doi:10.17222/mit.2015.301

\begin{abstract}
Copper is very difficult to be spot welded with conventional fusion-welding techniques due to a high thermal diffusivity. Friction-stir spot welding (FSSW) is a novel solid-state welding process, suitable and effective for spot welding copper. Commercially pure copper sheets of $3 \mathrm{~mm}$ thickness were spot welded using an industrial friction-stir welding machine. The spot welds were made by varying the tool rotational speed at three levels. The spot welds were characterized using light microscopy. The shear-fracture load was evaluated using a computerized tensile-testing machine. The results revealed that the tool rotational speed remarkably influenced the microstructure, the shear-fracture load and the mode of fracture.

Keywords: copper, friction-stir spot welding, microstructure, shear load
\end{abstract}

Zaradi velike toplotne prevodnosti se baker zelo težko točkasto vari pri običajnih postopkih varjenja z zlivanjem. Torno vrtilno točkasto varjenje (FSSW) je nov način varjenja v trdnem stanju, ki je primerno in primerljivo s torno vrtilnim točkastim varjenjem bakra. Bakrene pločevine, debeline $3 \mathrm{~mm}$, iz čistega komercialno dostopnega bakra, so bile točkasto zvarjene s torno vrtilnim točkastim varjenjem, z uporabo industrijske naprave za tovrstno varjenje. Točkasti zvari so bili izdelani pri treh hitrostih vrtenja orodja. Karakterizirani so bili z uporabo svetlobne mikroskopije. Strižna trdnost je bila ocenjena $\mathrm{z}$ uporabo računalniško vodenega nateznega stroja. Rezultati so pokazali, da hitrost vrtenja orodja močno vpliva na mikrostrukturo, strižno trdnost in način preloma.

Ključne besede: baker, torno vrtilno točkasto varjenje, mikrostruktura, strižna obremenitev

\section{INTRODUCTION}

Pure copper is extensively used in the optical and electronic industries owing to its excellent properties such as good ductility, high electrical, thermal conductivity and good corrosion resistance. The welding of copper is often encountered in the electrical, nuclear and automobile industries. ${ }^{1,2}$ Spot welding of pure copper is generally hard to do with conventional fusion welding because of the high thermal diffusivity, which is about 10 to 100 times higher than in many steels and nickel alloys. The heat input required is much higher than in almost any other material. Further, pure copper is susceptible to solidification cracking and blowhole formation. ${ }^{3,4}$ Friction-stir spot welding (FSSW) is a novel solid-state welding technique, promising for spot welding copper without the problems associated with fusion-welding techniques. ${ }^{5}$

FSSW is a derivative process based on friction-stir welding (FSW) which was developed at The Welding Institute in 1991. There are several differences between FSSW and FSW. One distinct difference is that there is no translation of tool during FSSW. FSW is commonly employed to join metallic plates in a butt configuration along the line of contact. On the other hand, FSSW is performed on thinner plates kept in a lap configuration. A rotating, non-consumable, cylindrical-shouldered tool with a pin is plunged, at a predetermined feed rate, into the overlapping plates to a depth slightly shorter than the total thickness of both plates. Frictional heat is generated between the plate material and the rotating tool, which plasticizes the material. The rotating action of the pin induces the material flow in both the circumferential and axial directions. The axial force applied along the tool axis forges the plasticized material and forms an annular, solid-state bond around the pin. At this moment, the rotating tool is retracted, leaving the exit hole behind. The major process parameters, which influence the joint strength, are the tool geometry, the tool rotational speed, the tool penetration depth and the dwell time. FSSW exhibits key advantages such as excellent mechanical properties, a low distortion, ease of handling, low cost, and clean working environment. ${ }^{6-8}$

The FSSW technique has been successfully used to spot weld aluminum ${ }^{9}$, magnesium ${ }^{10}$, steel $^{11}$ and plastics. $^{12}$ Both similar and dissimilar spot welds were reported in 


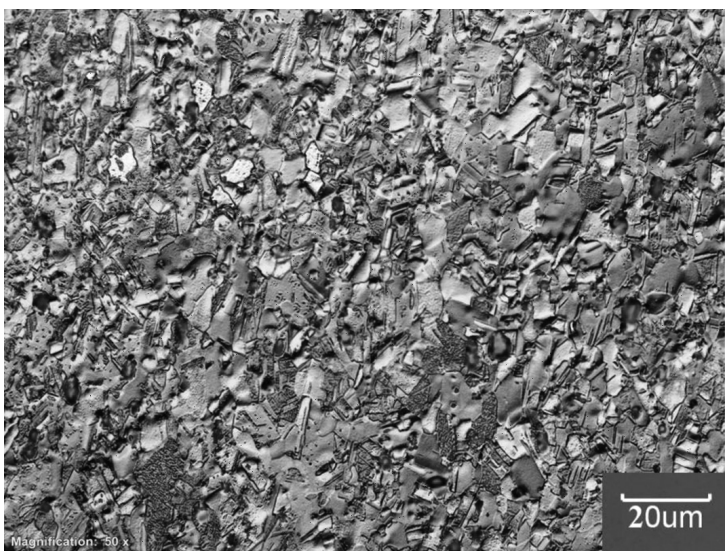

Figure 1: Light micrograph of pure copper

Slika 1: Svetlobni posnetek mikrostrukture čistega bakra

the literature ${ }^{13,14}$. FSSW of copper and its alloys is least explored. Z. Barlas ${ }^{15}$ spot welded pure copper and brass sheets using FSSW and analyzed the influences of the tool rotational speed, dwell period and material location on the microstructure and the tensile shear-fracture load (TSFL). He found that the welding parameters had an important influence on the TSFL and the failure mode. The TSFL increased with an increase in the tool rotational speed and dwell time. R. Heideman ${ }^{16}$ spot-welded AA6061 and pure-copper sheets and studied the effects of the tool pin length, the shoulder plunge depth, the welding time and the tool rotational speed on the TSFL. Literature on FSSW of pure copper is scantily. Therefore, the present work focuses on spot welding copper sheets of $3 \mathrm{~mm}$ using FSSW and analyzes the influence of the tool rotational speed on the TSFL.

\section{MATERIALS AND METHODS}

Commercially available pure copper sheets of $3 \mathrm{~mm}$ were used in this study. The optical photomicrograph of the as-received copper sheet is shown in Figure 1. Lap joint configuration was used to fabricate the spot welds where the rolling direction of the material was kept parallel to the loading directions and the joint was initially obtained by securing the sheets in position using mechanical clamps. A non-consumable tool made of high-carbon steel was used to fabricate the joints. The

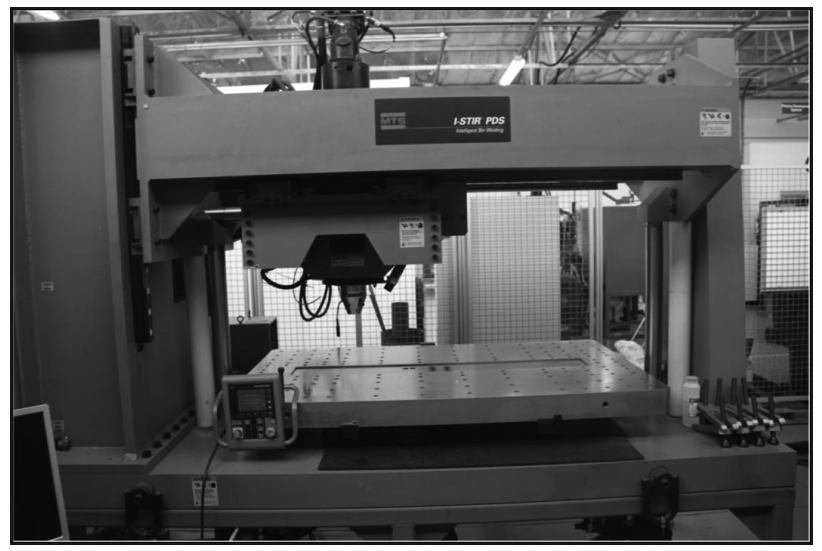

Figure 2: I-STIR friction-stir welding machine

Slika 2: I-STIR naprava za torno vrtilno varjenje

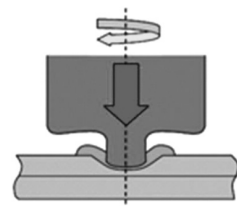

Plunging

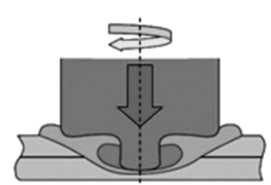

Stirring

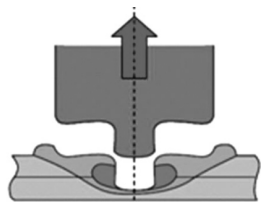

Drawing out
Figure 3: Schematic illustration of the friction-stir spot-welding process

Slika 3: Shematski prikaz postopka torno vrtilnega točkastega varjenja

tool had a shoulder of $18 \mathrm{~mm}$ and a conical profile of a diameter varying from $5 \mathrm{~mm}$ to $3 \mathrm{~mm}$ along the length of pin. The pin length was $5.7 \mathrm{~mm}$. An industrial-purpose FSW machine (I-STIR), depicted in Figure 2, was used for FSSW. The FSSW procedure and the welding cycle are depicted in Figure 3. The tool rotational speed was varied at three levels of $1200 \mathrm{~min}^{-1}, 1600 \mathrm{~min}^{-1}$ and 2000 $\min ^{-1}$. Other parameters were kept constant. The dwell period and axial force were $3 \mathrm{~s}$ and $10 \mathrm{kN}$, respectively. Spot welds were made on two sheets clamped in the lap configuration. Sufficient cooling was allowed between successive spot welds. The spot-welded copper sheet is shown in Figure 4. Six spot welds were made for each set of the process parameters. Specimens were machined from the welded sheets and polished semi-automatically in a polishing machine (Struers LaboPol 25). The mirror-polished specimens were etched with a color etchant containing $20 \mathrm{~g}$ of chromic acid, $2 \mathrm{~g}$ of sodium

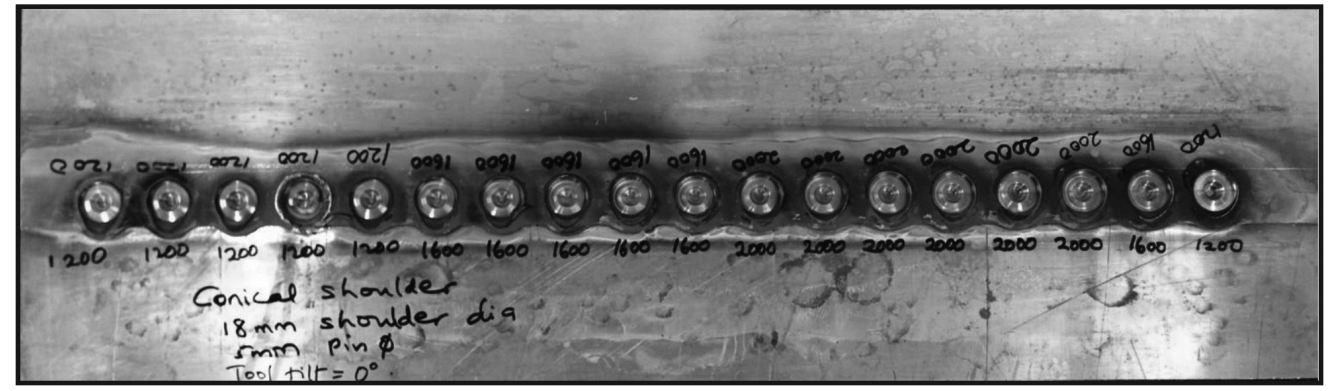

Figure 4: Friction-stir spot-welded sheet

Slika 4: Torno vrtilno točkasto zvarjena pločevina 
sulfate and $1.7 \mathrm{~mL}$ of $\mathrm{HCl}(35 \%)$ in $100 \mathrm{~mL}$ distilled water. The macrostructure was recorded using a stereo microscope (OLYMPUS SZX16). The microstructure was observed using a metallurgical microscope (OLYMPUS BX51M). The TSFL was evaluated using a computerized tensile tester (INSTRON 1195) at a crosshead speed of $2 \mathrm{~mm} / \mathrm{min}$.

\section{RESULTS AND DISCUSSION}

Macrographs of the copper friction-stir spot-welded as a function of the tool rotational speed are presented in Figure 5. It is possible to spot weld successfully using the chosen parameters. The weld zones are almost symmetrical with respect to the axis of the keyhole. The tool rotation generates frictional heat, which plasticizes the copper. The force applied along the axis of the tool promotes the vertical motion of the plasticized copper. The axial force further consolidates the plasticized copper and a spot joint is formed. The joint width is clearly visible on all the joints. Considerable areas of both the top and bottom sheets are bonded together. The hook does not extend to the keyhole area, which indicates bonding between the sheets. The bond width was measured and was found to be $(7.5,8.5$ and 10$) \mathrm{mm}$, respectively, at the selected tool rotational speeds. An increase in the tool speed improves the bond width because the frictional-heat generation depends upon the tool rotational speed. ${ }^{17}$ The higher the tool rotational speed, the higher is the heat generation. Hence, more copper is plasticized and the bond width increases.

Regions with different microstructures were observed on these macrographs. They are the stir zone (SZ), the
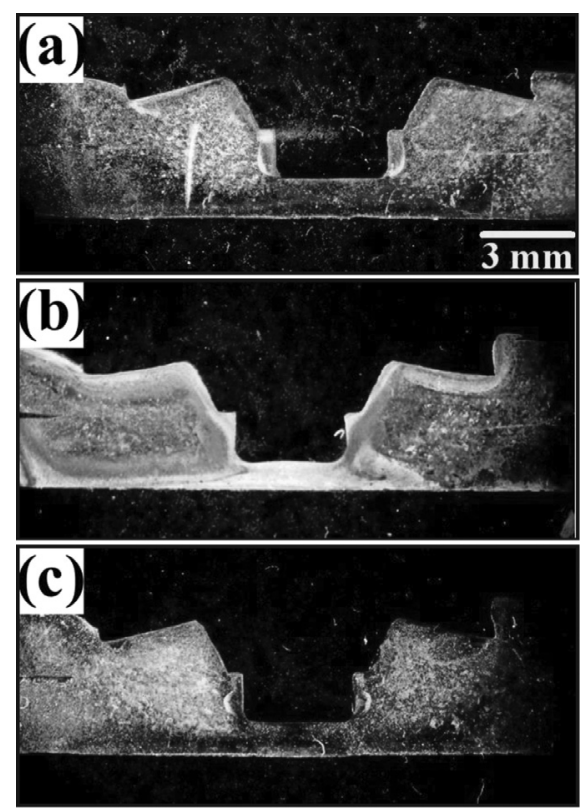

Figure 5: Macrographs of friction-stir spot-welded copper at: a) $1200 \mathrm{~min}^{-1}$, b) $1600 \mathrm{~min}^{-1}$ and c) $2000 \mathrm{~min}^{-1}$

Slika 5: Makro posnetek torno vrtilno točkasto zvarjenega bakra pri: a) $1200 \mathrm{~min}^{-1}$, b) $1600 \mathrm{~min}^{-1}$ in c) $2000 \mathrm{~min}^{-1}$ thermomechanically affected zone (TMAZ), the heataffected zone (HAZ) and the base copper. These regions are presented in the micrographs in Figure 6 as a function of the tool rotational speed. The stir zone is adjacent to the keyhole area and displays very fine grains. FSSW was derived from FSW. The plasticized material in FSW undergoes dynamic recrystallization, which results in the formation of fine grains. The width of the stir zone reduces as the tool rotational speed is increased due to a higher heat input. The TMAZ region presents slightly elongated grains with an array of oxide particles. The shearing of the plasticized material from the advancing side to the retreading side causes the grains in this region to elongate. The width of the TMAZ is found to reduce with an increase in the tool rotational speed. The third
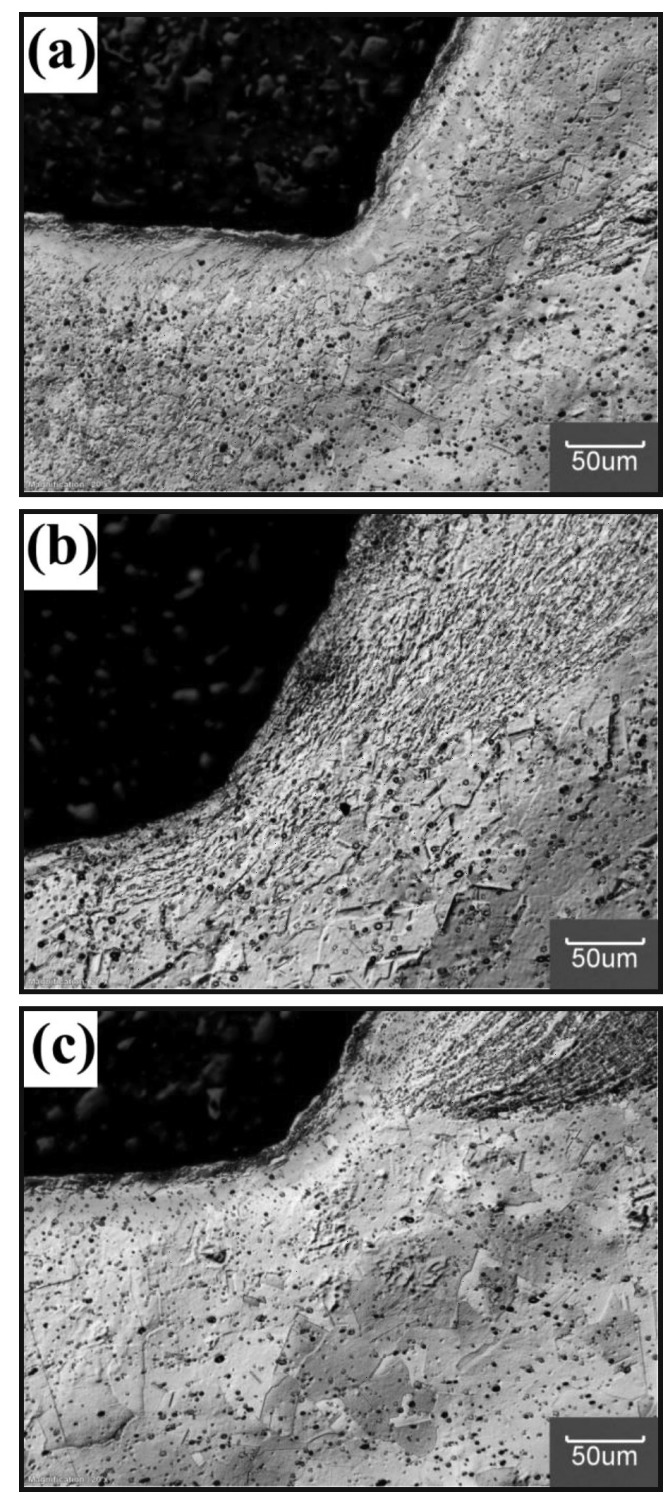

Figure 6: Light micrographs of the transition zone of friction-stir spot-welded copper at: a) $1200 \mathrm{~min}^{-1}$, b) $1600 \mathrm{~min}^{-1}$ and c) $2000 \mathrm{~min}^{-1}$ Slika 6: Svetlobni posnetki mikrostrukture prehodne cone torno vrtilno točkasto zvarjenega bakra pri: a) $1200 \mathrm{~min}^{-1}$, b) $1600 \mathrm{~min}^{-1}$ in c) $2000 \mathrm{~min}^{-1}$ 

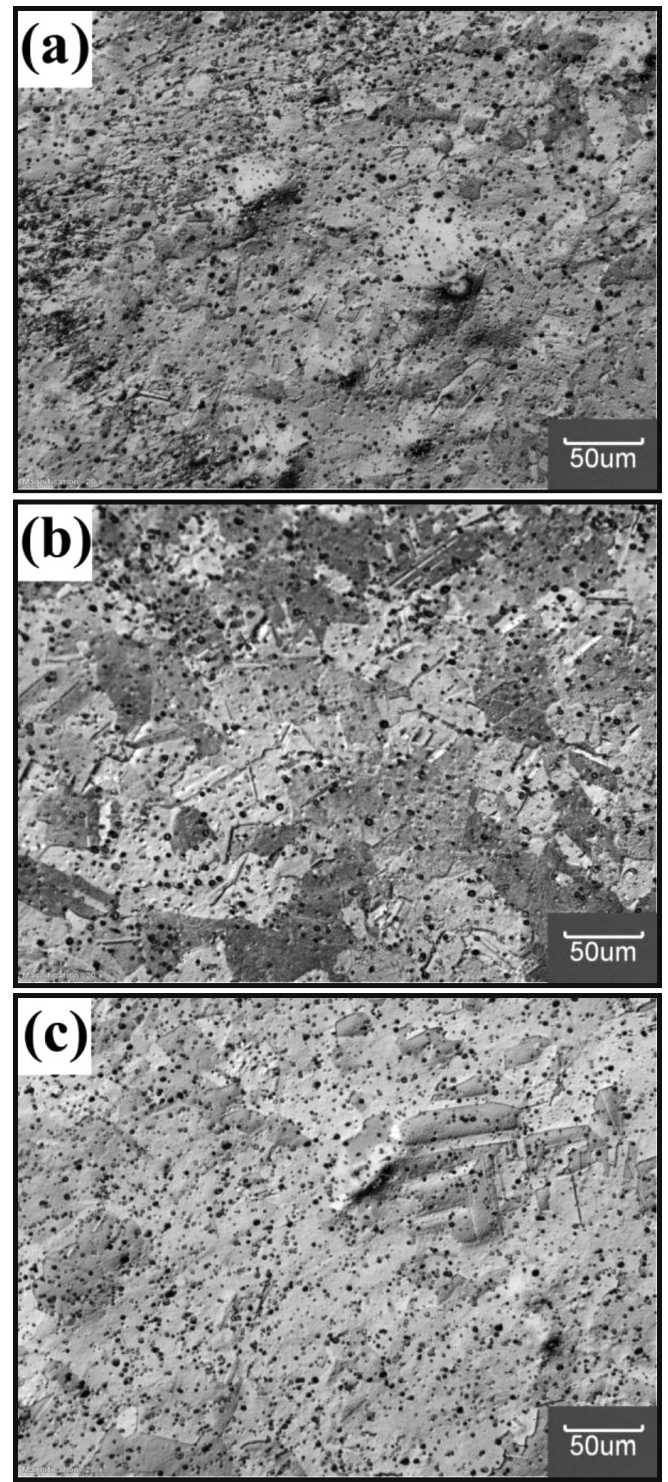

Figure 7: Light micrographs of the heat-affected zone of friction-stir spot-welded copper at: a) $1200 \mathrm{~min}^{-1}$, b) $1600 \mathrm{~min}^{-1}$ and c) $2000 \mathrm{~min}^{-1}$ Slika 7: Svetlobni posnetki mikrostrukture toplotno vplivane cone torno vrtilno točkasto zvarjenega bakra pri: a) $1200 \mathrm{~min}^{-1}$, b) $1600 \mathrm{~min}^{-1}$ in c) $2000 \mathrm{~min}^{-1}$

region, the HAZ, contains coarse grains. The coarseness of the grains increases with an increase in the tool rotational speed as presented in Figure 7.

A higher frictional heat causes the grains to become coarse. The grain size in the HAZ region is higher compared to the grain size of the as-received pure copper in Figure 1. This region is clearly influenced by the frictional heat generated during FSSW, leading to the grain growth. The stir zone is very thin at the higher tool rotational speed of $2000 \mathrm{~min}^{-1}$. The higher heat causes the recrystallized grains to grow further and diminishes the width of the stir zone. The microstructure of the unbonded zone is presented in Figure 8. The grains of the upper and lower sheets are not uniform. The grains in the upper sheet are coarser than those in the lower sheet.
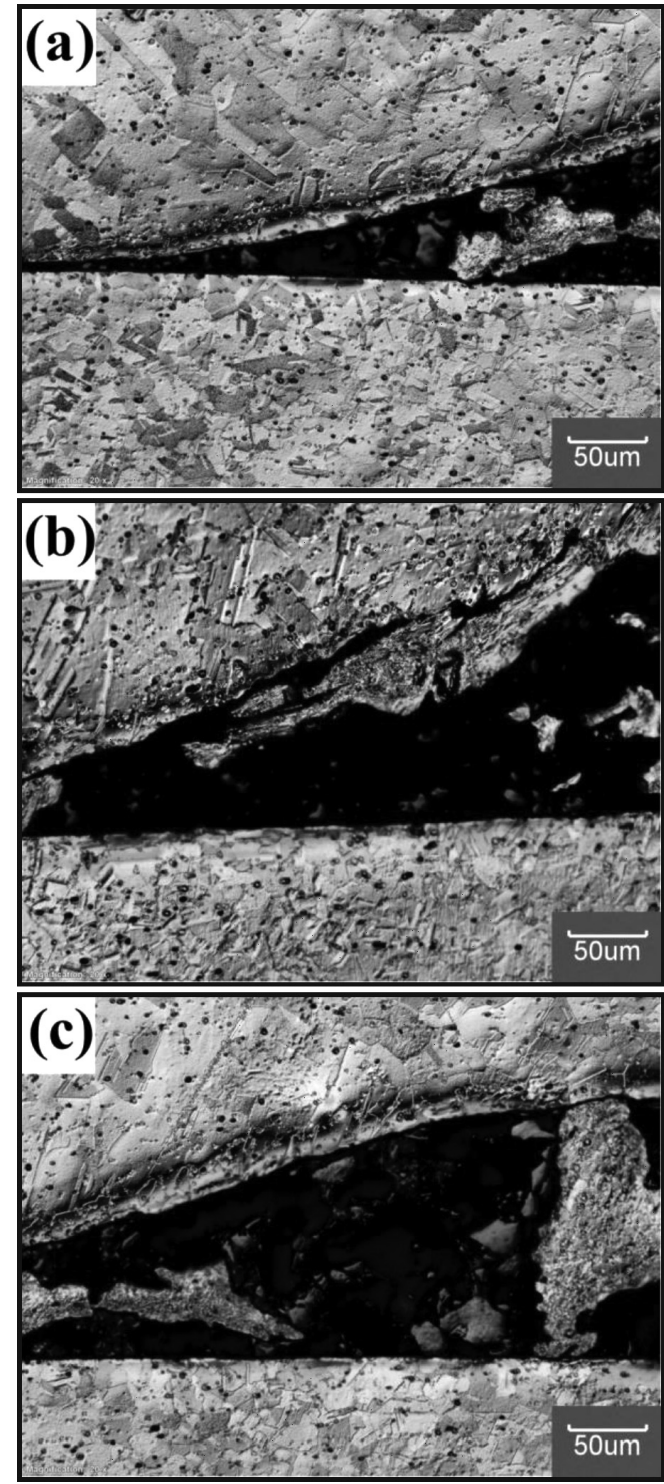

Figure 8: Light micrographs of the unbonded zone of friction-stir spot-welded copper at: a) $1200 \mathrm{~min}^{-1}$, b) $1600 \mathrm{~min}^{-1}$ and c) $2000 \mathrm{~min}^{-1}$ Slika 8: Svetlobni posnetki nezvarjenega področja torno vrtilno točkastega zvara bakra pri: a) $1200 \mathrm{~min}^{-1}$, b) $1600 \mathrm{~min}^{-1}$ in c) $2000 \mathrm{~min}^{-1}$

This can be attributed to the proximity of each sheet to the tool shoulder. The upper sheet receives more heat input compared to the lower sheet, causing the grains to become coarser.

The influence of the tool rotational speed on the TSFL is depicted in Figure 9. It is evident from the figure that the increase in the tool rotational speed increased the TSFL. Although the increase in the tool rotational speed caused grain growth in different regions across the joint, the TSL improved upon the increased tool rotational speed because the TSFL depends upon the joint width and the hook position from the stir-zone area. A hook is formed in a FSSW joint as the material from the bottom sheet flows upwards during the process. The distance of the hook from the stir-zone area determines the load-carrying capacity of the joint. The hook is not 


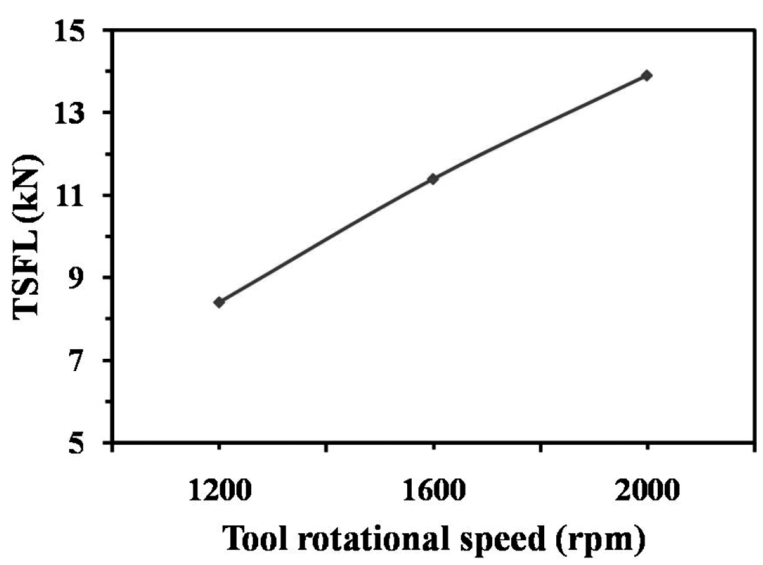

Figure 9: Effect of tool rotational speed on tensile shear load of friction-stir spot-welded copper

Slika 9: Vpliv hitrosti vrtenja orodja na natezno strižno obremenjenega torno vrtilno zvarjenega bakra

clear in the macrograph in Figure 1 due to the annealing effect of copper during FSSW.

The other factor is the bond width. The bond width increased with an increase in the tool rotational speed. This provided more tangential area to resist the external load. Hence, the TSFL increased as the tool rotational speed was increased. The photographs of failed specimens are shown in Figure 10. The failed specimens de-

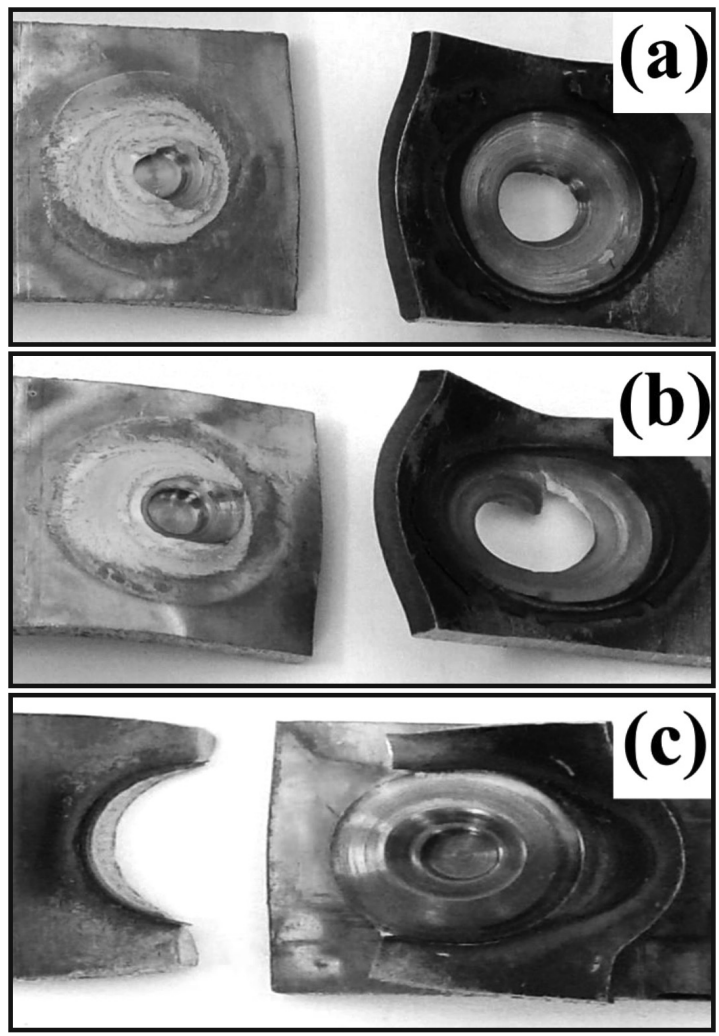

Figure 10: Images of failed sheets at tool rotational speeds of: a) 1200 $\mathrm{min}^{-1}$, b) $1600 \mathrm{~min}^{-1}$ and c) $2000 \mathrm{~min}^{-1}$

Slika 10: Posnetki porušenih pločevin pri hitrosti vrtenja orodja: a) $1200 \mathrm{~min}^{-1}$, b) $1600 \mathrm{~min}^{-1}$ in c) $2000 \mathrm{~min}^{-1}$

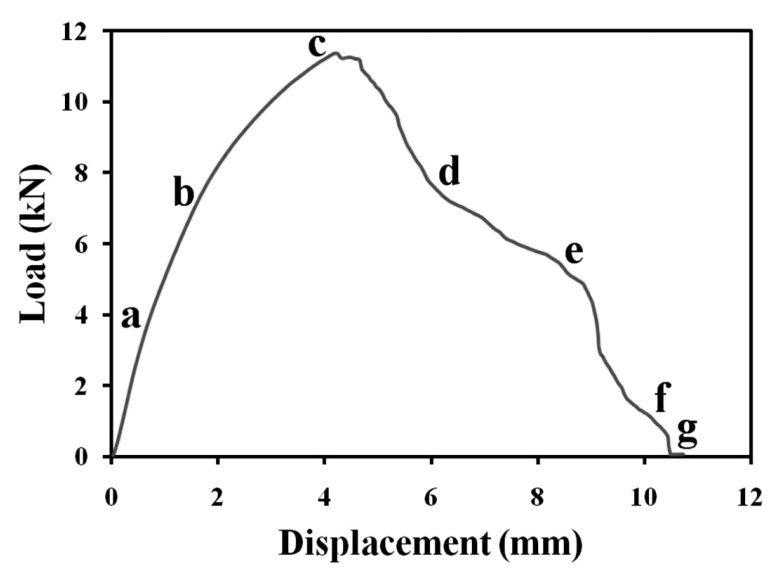

Figure 11: Load-versus-displacement graph for a tensile shear-tested specimen at the tool rotational speed of $1600 \mathrm{~min}^{-1}$

Slika 11: Odvisnost obremenitve in raztezka pri nateznem strižnem preizkusu vzorcev pri hitrosti vrtenja orodja $1600 \mathrm{~min}^{-1}$

monstrate different modes of failure. The nugget pull-out failure is observed at the tool rotational speeds of $1200 \mathrm{~min}^{-1}$ and $1600 \mathrm{~min}^{-1}$. It can be inferred from the
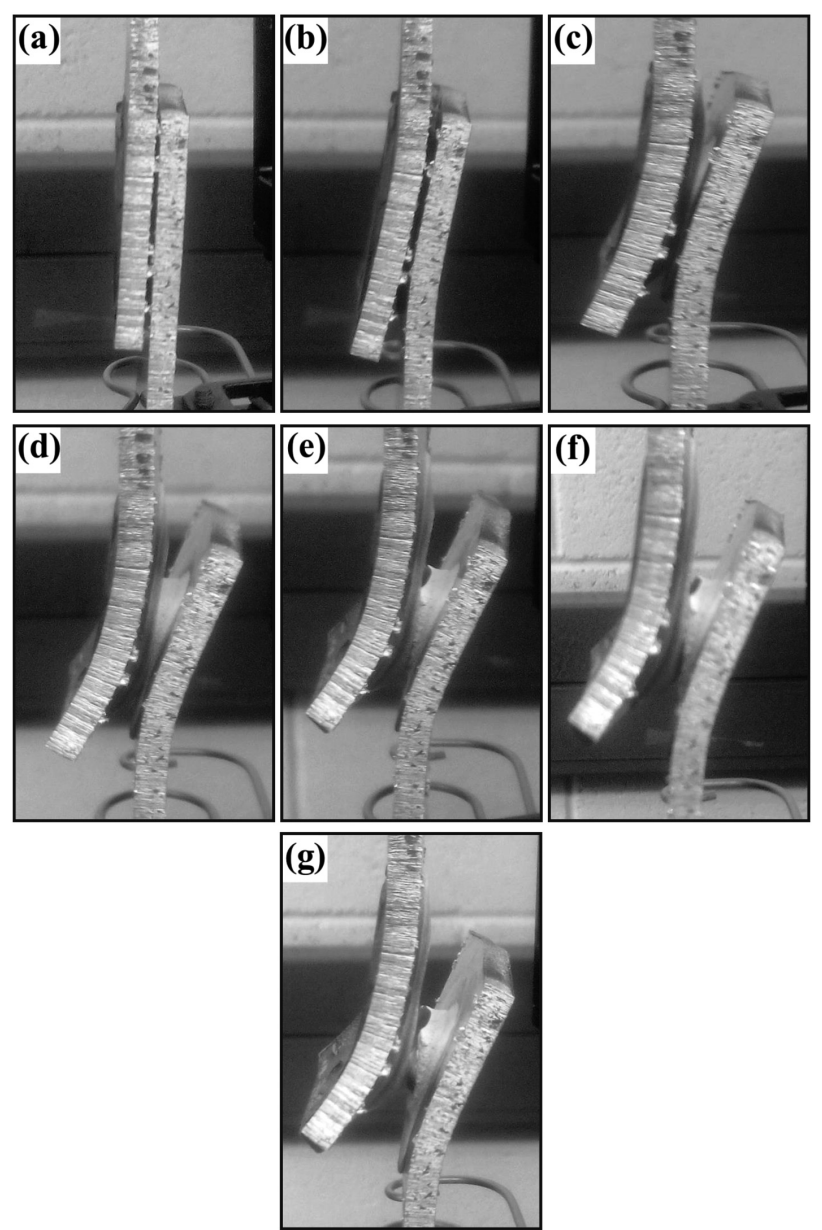

Figure 12: Images of tensile shear specimens during loading as marked in Figure 11

Slika 12: Posnetki nateznih strižnih vzorcev med obremenjevanjem, kot je prikazano na Sliki 11 
photographs (Figures 10a and 10b) that the nugget pull-out originated from the bottom of the keyhole area. The diameter of the hole in the upper failed sheet is higher at $1500 \mathrm{~min}^{-1}$ than $1200 \mathrm{~min}^{-1}$. This is due to an increase in bond width, which provided a wider metallurgical bonding. The mode of failure at the tool rotational speed of $2000 \mathrm{~min}^{-1}$ is tearing. The tearing started circumferentially around the unbonded region and could not pull the nugget out because the higher bond width at $2000 \mathrm{~min}^{-1}$ caused the sheet to tear like a tensile specimen.

The load-versus-displacement curve for the tensile shear-tested specimen at the tool rotational speed of $1600 \mathrm{~min}^{-1}$ is presented in Figure 11. The load increases with a constant slope until point 'c' is reached. Corresponding photographs in Figure 12 show details of the points marked in Figure 11. As the load is increased to point ' $b$ ', the specimen bends. The axis of the normal load does not coincide with the centre of the tested specimen, which creates a small moment causing the bending. The specimen starts to yield, i.e., the nugget pull-out commences at point ' $c$ '. The load does not drop sharply to zero, unlike in the cases of tensile failures, because the nugget pull-out is not instant. The nugget pulls out gradually as the separation increases until point ' $\mathrm{g}$ ' is reached. The load drops to zero, which indicates a complete separation of both sheets.

\section{CONCLUSIONS}

Commercially pure copper sheets were successfully spot welded using the novel FSSW technique. The influence of the key processing parameter, the tool rotational speed, on the microstructure and TSFL was analyzed. The increase in the tool rotational speed increased the bond width and coarsened the grains in the stir zone and HAZ. The TSFL improved as the tool rotation increased. The nugget pull-out failure took place at $1200 \mathrm{~min}^{-1}$ and $1600 \mathrm{~min}^{-1}$ and the tear-out failure took place at $2000 \mathrm{~min}^{-1}$.

\section{REFERENCES}

${ }^{1}$ K. Surekha, A. Els-Botes, Development of high strength, high conductivity copper by friction stir processing, Materials and Design, 32 (2011), 911-916, doi:10.1016/j.matdes.2010.08.028

${ }^{2}$ P. Xue, B. L. Xiao, Q. Zhang, Z. Y. Ma, Achieving friction stir welded pure copper joints with nearly equal strength to the parent metal via additional rapid cooling, Scripta Materialia, 64 (2011), 1051-1054, doi:10.1016/j.scriptamat.2011.02.019
${ }^{3}$ R. M. Leal, N. Sakharova, P. Vilaca, D. M. Rodrigues, A. Loureiro, Effect of shoulder cavity and welding parameters on friction stir welding of thin copper sheets, Science and Technology of Welding and Joining, 16 (2011), 146-152, doi:10.1179/1362171810Y. 0000000005

${ }^{4}$ W. B. Lee, S. B. Jung, The joint properties of copper by friction stir welding, Materials Letters, 58 (2004), 1041-1046, doi:10.1016/ j.matlet.2003.08.014

${ }^{5}$ M. I. Khan, M. L. Kuntz, P. Su, A. Gerlich, T. North, Y. Zhou, Resistance and friction stir spot welding of DP600: a comparative study, Science and Technology of Welding and Joining, 12 (2007), 175-182, doi:10.1179/174329307X159801

${ }^{6}$ J. Jeon, S. Mironov, Y. S. Sato, H. Kokawa, S. H. C. Park, S. Hirano, Friction stir spot welding of single-crystal austenitic stainless steel, Acta Materialia, 59 (2011), 7439-7449, doi:10.1016/j.actamat. 2011.09.013

${ }^{7}$ Y. F. Sun, H. Fujii, N. Takaki, Y. Okitsu, Microstructure and mechanical properties of mild steel joints prepared by a flat friction stir spot welding technique, Materials and Design, 37 (2012), 384-392, doi:10.1016/j.matdes.2012.01.027

${ }^{8}$ S. Bozzi, A. L. H. Etter, T. Baudin, B. Criqui, J. G. Kerbiguet, Intermetallic compounds in Al 6016/IF-steel friction stir spot welds, Materials Science and Engineering A, 527 (2010), 4505-4509, doi:10.1016/j.msea.2010.03.097

${ }^{9}$ G. Buffa, L. Fratini, M. Piacentini, Journal of Materials Processing Technology, 208 (2008), 309-317, doi:10.1016/j.jmatprotec.2008. 01.001

${ }^{10}$ Y. H. Yina, N. Sun, T. H. North, S. S. Hu, On the influence of tool path in friction stir spot welding of aluminum alloys, Journal of Materials Processing Technology, 210 (2010), 2062-2070, doi:10.1016/j.jmatprotec.2010.07.029

${ }^{11}$ C. C. P. Mazzaferro, T. S. Rosendo, M. A. D. Tiera, J. A. E. Mazzaferro, J. F. Dos Santos, T. R. Strohaecker, Microstructural and Mechanical Observations of Galvanized TRIP Steel after Friction Stir Spot Welding, Materials and Manufacturing Processes, 30 (2015), 1-14, doi:10.1080/10426914.2015.1004699

${ }^{12}$ P. H. F. Oliveira, S. T. A. Filho, J. F. dos Santos, E. Hage, Preliminary study on the feasibility of friction spot welding in PMMA, Materials Letters, 64 (2010), 2098-2101, doi:10.1016/j.matlet. 2010.06.050

${ }^{13}$ M. Yamamoto, A. Gerlich, T. H. North, K. Shinozaki, Science and Technology of Welding and Joining, 13 (2008), 583-592, doi:10.1179/174329308X349520

${ }^{14}$ V. X. Tran, J. Pan, T. Pan, Fatigue behavior of spot friction welds in lap-shear and cross-tension specimens of dissimilar aluminum sheets, International Journal of Fatigue, 32 (2010), 1022-1041, doi:10.1016/j.ijfatigue.2009.11.009

${ }^{15} \mathrm{Z}$. Barlas, Effect of friction stir spot weld parameters on $\mathrm{Cu} / \mathrm{CuZn} 30$ bimetal joints, International Journal of Advanced Manufacturing Technology, 80 (2015), 161-170, doi:10.1007/s00170-015-6998-1

${ }^{16}$ R. Heideman, C. Johnson, S. Kou, Metallurgical analysis of $\mathrm{Al} / \mathrm{Cu}$ friction stir spot welding, Science and Technology of Welding and Joining, 15 (2010), 597-604, doi:10.1179/136217110X1278588 9549985

${ }^{17}$ R. S. Mishra, Z. Y. Ma, Friction stir welding and processing, Materials Science and Engineering R, 50 (2005), 1-78, doi:10.1016/ j.mser.2005.07.001 